\title{
Epidemiology of hospitalized patients with COVID-19 in a tertiary care hospital
}

\author{
Guadalupe Maza-De La Torre, ${ }^{1}$ Edgardo A. Montelongo-Mercado, ${ }^{2}$ Héctor F. Noyola-Villalobos, ${ }^{3}$ \\ Antonio García-Ruiz, ${ }^{4}$ Sergio Hernández-Díaz, ${ }^{5}$ Martha Santiago-Torres, ${ }^{6}$ Luis F. Moreno-Delgado, ${ }^{7}$ \\ Ricardo Carrera-Altamirano, ${ }^{8}$ Omar E. Muñoz-Monroy, ${ }^{9}$ Adriana Martínez-Cuazitl, ${ }^{10}$ \\ Mayra A. Martínez-González, ${ }^{10}$ Martín U. Vázquez-Medina, ${ }^{10}$ Óscar Alvarado-Uribe, ${ }^{11}$ \\ Julián Torres-Vázquez, ${ }^{12}$ Aldo Figueroa-Peña ${ }^{13}$ and Iván N. Martínez-Salazar10*
}

${ }^{1}$ Directorate; ${ }^{2}$ Sub-directorate-General; ${ }^{3}$ Medical Sub-directorate; ${ }^{4}$ Technical Sub-directorate; ${ }^{5}$ Teaching and Research Area Head Office; ${ }^{6}$ Medical Area Head Office; ' Surgery Area Head Office; ${ }^{8}$ Sub-directorate-General Liaison Group Head Office; 9 Internal Medicine Department Head Office; ${ }^{10}$ Department of Research; ${ }^{11}$ Surgical Residents Head Office; ${ }^{12}$ Medical Residents Head Office; ${ }^{13}$ Escuela Militar de Graduados de Sanidad. Secretaría de la Defensa, Hospital Central Militar, Mexico City, Mexico

\begin{abstract}
Introduction: COVID-19, caused by the betacoronavirus SARS-CoV-2, has overwhelmed the world's health systems. Objective: To describe the epidemiological characteristics of patients treated in a tertiary care hospital. Methods: $A$ retrospective cohort study of patients diagnosed with or suspected of having COVID-19 from March 23 to July 31, 2020 was conducted. Results: 4,401 patients were hospitalized at Central Military Hospital, out of which $35 \%$ were beneficiaries, $26 \%$ civilians, $28 \%$ active military personnel, and only $11 \%$, retired military personnel. Male gender predominated, both in hospitalized patients and in those who died, as well as the O+ group and absence of comorbidities; among the observed comorbidities, the main ones were overweight and diabetes. Hospitalized patients' median age was 49 years, while median age of those who died was 62 years; women older than 51 years had a higher risk of dying. Adjusted case fatality rate was $18.5 \%$; $50 \%$ died within the first six days. Conclusions: In this study, the epidemiological characteristics and main comorbidities in Mexican patients with SARS-CoV-2 infection were identified.
\end{abstract}

KEY WORDS: Epidemiology. COVID-19. Tertiary care hospital.

\section{Epidemiología de los pacientes hospitalizados con COVID-19 en un hospital de tercer nivel}

\section{Resumen}

Introducción: COVID-19, causada por el betacoronavirus SARS-CoV-2, ha saturado los sistemas de salud del mundo. Objetivo: Describir las características epidemiológicas de los pacientes atendidos en un hospital de tercer nivel. Métodos: Se realizó una cohorte retrospectiva de pacientes con diagnóstico o sospecha de COVID-19, del 23 de marzo al 31 de julio de 2020. Resultados: En el Hospital Central Militar se hospitalizaron 4401 pacientes, $35 \%$ derechohabientes, $26 \%$ civiles, $28 \%$ militares en activo y solo $11 \%$, militares retirados. Predominó el sexo masculino, tanto en los pacientes hospitalizados como en los que fallecieron, el grupo O+ y la ausencia de comorbilidades; entre las comorbilidades que se observaron, las principales fueron el sobrepeso y la diabetes. La mediana de edad de los pacientes hospitalizados fue de 49 años, mientras que 62 años

Correspondence:

*Iván N. Martínez-Salazar

E-mail: inmartinezs.dn11@ sedena.gob.mx
Gac Med Mex. 2021;157:237-244

Contents available at PubMed

www.gacetamedicademexico.com 0016-3813/@ 2021 Academia Nacional de Medicina de México, A.C.. Published by Permanyer. This is an open access article under the CC BY-NC-ND license (http://creativecommons.org/licenses/by-nc-nd/4.0/). 
fue la edad de quienes fallecieron; las mujeres mayores de 51 años tuvieron mayor riesgo de fallecer. La tasa de letalidad ajustada fue de $18.5 \%$; 50 \% falleció durante los primeros seis días. Conclusiones: En este estudio se lograron identificar las características epidemiológicas y se destacaron las principales comorbilidades en pacientes mexicanos con infección por SARS-CoV-2.

PALABRAS CLAVE: Epidemiología. COVID-19. Hospital de tercer nivel.

\section{Introduction}

In December 2019, coronavirus disease 2019 (COVID-19) emerged in Wuhan, China, and generated a public health emergency of international concern due to its rapid spread, overburdening health systems. Its clinical presentation varies from asymptomatic cases to the development of severe pneumonia. ${ }^{1}$

In Mexico, the first case was recorded on February 28, 2020; by September 11, 2020, 652,364 cases and 69,649 deaths had been reported. ${ }^{2}$ The General Directorate of Epidemiology generated various strategies and guidelines for epidemiological surveillance, which include identification of cases, contact tracing, timely notification to the National System of Epidemiological Surveillance (SINAVE - Sistema Nacional de Vigilancia Epidemiológica), as well as aspects for adequate collection, handling and shipment of samples and analytical control available for the confirmation of cases. COVID-19 diagnosis is established with the performance of the reverse transcriptase-polymerase chain reaction (RT-PCR) assay together with clinical and radiological findings. ${ }^{3}$

The purpose of this work was to describe the demographic and epidemiological characteristics of patients hospitalized at Central Military Hospital from March 23 to July 31, 2020.

\section{Methods}

The medical records of patients hospitalized for COVID-19 were reviewed according to the criteria established by SINAVE, between March 23 and July 31, 2020 in a tertiary care hospital, in compliance with the guidelines of the Declaration of Helsinki. ${ }^{3}$

The comorbidities that were considered were those known and reported by the patients. The frequency of overweight and obesity was determined according to the body mass index (BMI) in a sample of 656 confirmed patients.

Categorical variables were reported as frequencies and percentages; continuous variables were described in medians and interquartile ranges (IQR).
The comparison of comorbidities, type of comorbidity, gender and age groups between suspected and confirmed cases was carried out using Fisher's exact test and Mann-Whitney's U-test for continuous variables. Median survival was determined by Kaplan-Meier analysis. A p-value $<0.05$ was considered to be statistically significant; the analysis was carried out with the SPSS program, version 27.

\section{Results}

Four-thousand four hundred and one patients were admitted to the Central Military Hospital, in Mexico City, between March 23 and July 31, 2020. The highest admission peak was between May 27 and June 24 (Fig. 1); the day with the highest number of admissions was May 29 (106 patients).

The hospital was reconverted into a COVID hospital; it complied with the guidelines established on April 5, 2020 and allowed the care of non-beneficiary patients; $26 \%$ of hospitalized patients were civilians (Table 1). ${ }^{4}$

Among the patients admitted for COVID-19, male gender and blood group O+ predominated; median age was 49 years (Table 1). The age range that predominated was 41 to 50 years (Table 2).

Most admitted patients had no known comorbidities. The predominant comorbidity was diabetes, followed by hypertension and obesity (Table 1); however, in 656 confirmed patients, median BMI was recorded to be $27.1 \mathrm{~kg} / \mathrm{m}^{2}$, which indicates that $76.1 \%$ had overweight or obesity (Table 3 ).

Table 4 shows the characteristics of the patients who died $(n=1,059)$, with a crude case fatality rate of $24 \%$ and an adjusted case fatality rate of $18.5 \%$. The period with the highest case fatality rate was between May 20 and June 24, as shown in figure 2, with a new increase from July 15 on.

Overall, the male gender and blood group O+ predominated; the rate of deceased males/hospitalized males was higher than the rate of deceased females/ hospitalized females (Tables 4 and 5).

Median age of the patients who died was 62 years (Table 4). The case fatality rate percentage was 


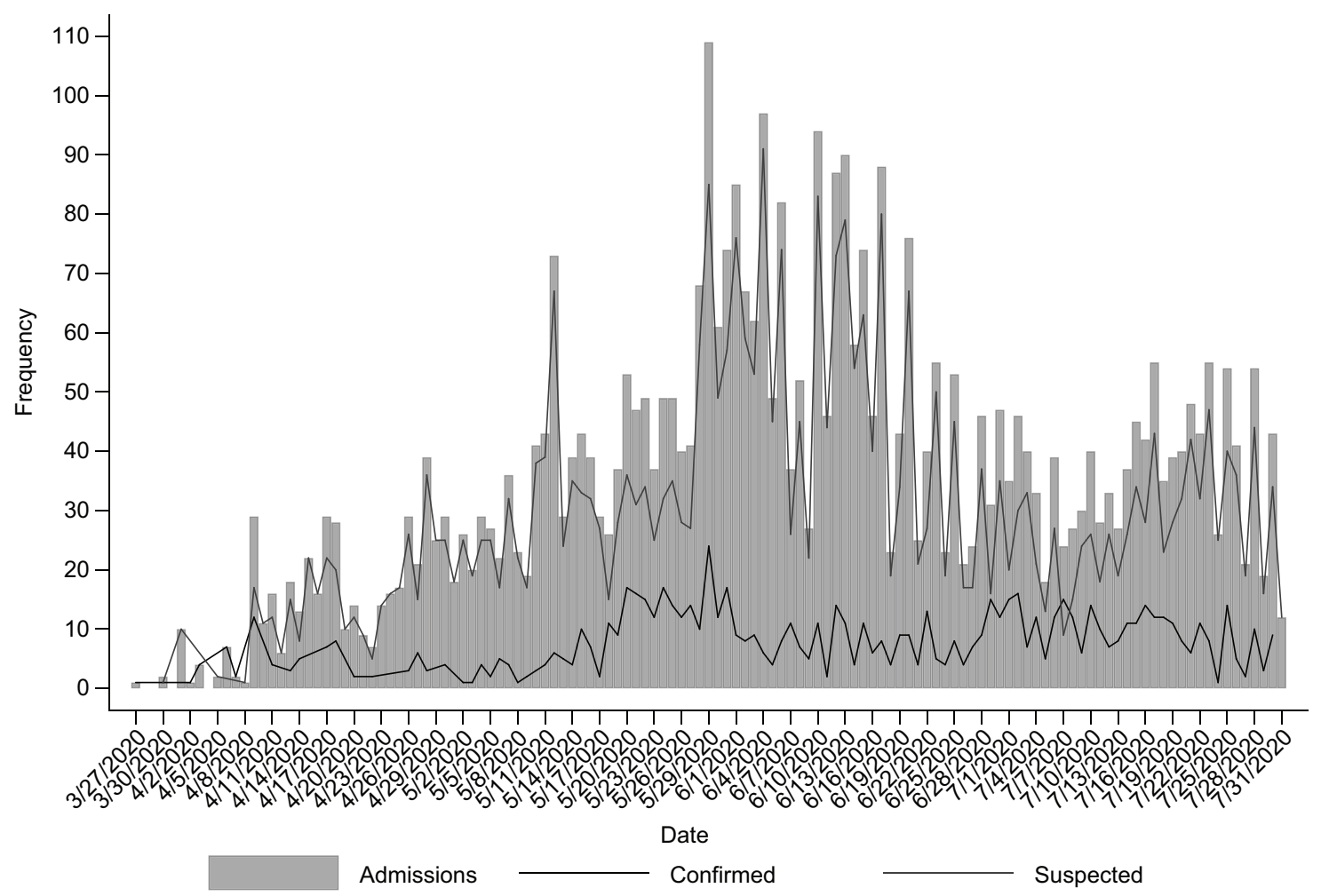

Figure 1. Frequency of COVID-19-diagnosed patients admissions per day at Central Military Hospital, Mexico City. Total admissions are shown, as well as admissions of patients with suspected COVID-19 (patients who meet clinical criteria with no RT-PCR test) or RT-PCR-confirmed patients.

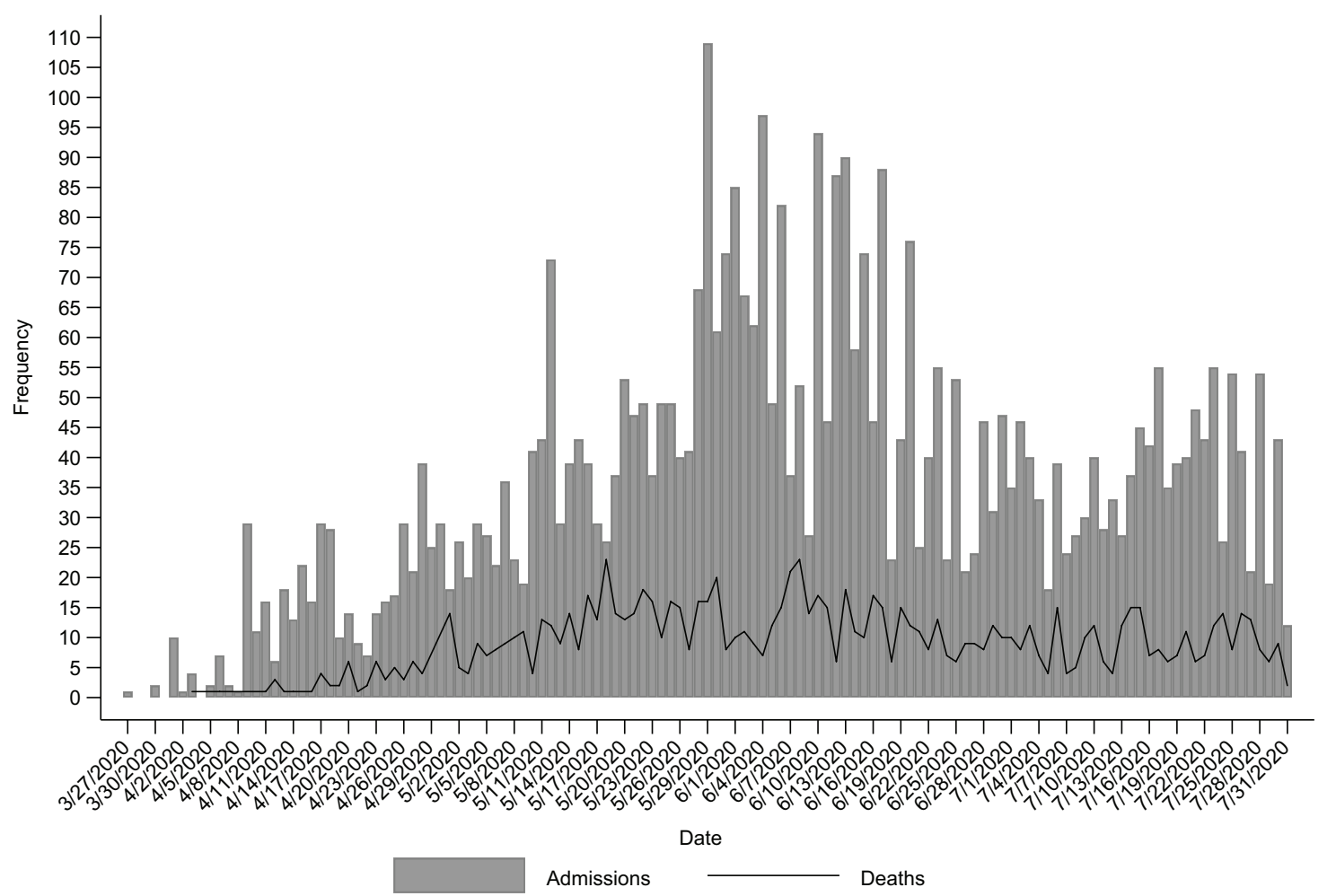

Figure 2. Frequency of admissions and deaths of patients diagnosed with or suspicious of having COVID-19 per day at Central Military Hospital, Mexico City. Total hospitalizations are shown, as well as patients who died from COVID-19. 
Table 1. Patients with COVID-19 hospitalized at Central Military Hospital, Mexico City

\begin{tabular}{|c|c|c|c|c|c|c|c|}
\hline \multirow[t]{2}{*}{ Variable } & \multicolumn{2}{|c|}{$\begin{array}{c}\text { Total } \\
(n=4,401)\end{array}$} & \multicolumn{2}{|c|}{$\begin{array}{c}\text { Suspected } \\
(\mathrm{n}=3,553,81 \%)\end{array}$} & \multicolumn{2}{|c|}{$\begin{array}{c}\text { Confirmed } \\
(n=848,21 \%)\end{array}$} & \multirow[t]{2}{*}{ p } \\
\hline & Median & IQR & Median & IQR & Median & IQR & \\
\hline \multirow[t]{2}{*}{ Age } & 49 & 38,72 & 49 & 38,62 & 49 & $39.5,62$ & $0.5^{\star \star}$ \\
\hline & $\mathrm{n}$ & $\%$ & $\mathrm{n}$ & $\%$ & $\mathrm{n}$ & $\%$ & \\
\hline $\begin{array}{l}\text { Situation } \\
\text { Active military personnel } \\
\text { Retired military personnel } \\
\text { Beneficiary } \\
\text { Civilian }\end{array}$ & $\begin{array}{c}1,225 \\
491 \\
1,538 \\
1,147\end{array}$ & $\begin{array}{l}28 \\
11 \\
35 \\
26\end{array}$ & $\begin{array}{c}908 \\
392 \\
1,305 \\
948\end{array}$ & $\begin{array}{l}26 \\
11 \\
37 \\
27\end{array}$ & $\begin{array}{c}317 \\
99 \\
233 \\
199\end{array}$ & $\begin{array}{l}37 \\
12 \\
27 \\
23\end{array}$ & \\
\hline $\begin{array}{l}\text { Gender } \\
\text { Males } \\
\text { Females }\end{array}$ & $\begin{array}{l}2,666 \\
1,735\end{array}$ & $\begin{array}{l}61 \\
39\end{array}$ & $\begin{array}{l}2,089 \\
1,464\end{array}$ & $\begin{array}{l}59 \\
41\end{array}$ & $\begin{array}{l}577 \\
271\end{array}$ & $\begin{array}{l}68 \\
32\end{array}$ & $<0.001^{*}$ \\
\hline $\begin{array}{l}\text { Blood group } \\
\mathrm{O}_{+} \\
\mathrm{A}_{+} \\
\mathrm{B}+ \\
\mathrm{O}_{-} \\
\mathrm{A}_{-} \\
\mathrm{B}- \\
\mathrm{AB}+ \\
\text { No record }\end{array}$ & $\begin{array}{c}3,561 \\
494 \\
130 \\
52 \\
5 \\
5 \\
28 \\
131\end{array}$ & $\begin{array}{c}83 \\
12 \\
3 \\
1 \\
0.1 \\
0.1 \\
1 \\
-\end{array}$ & $\begin{array}{c}2,838 \\
402 \\
99 \\
45 \\
3 \\
4 \\
24 \\
119\end{array}$ & $\begin{array}{c}80 \\
11 \\
2.8 \\
1.3 \\
0.08 \\
0.1 \\
0.6 \\
-\end{array}$ & $\begin{array}{c}723 \\
92 \\
31 \\
7 \\
2 \\
1 \\
4 \\
12\end{array}$ & $\begin{array}{c}85 \\
10.9 \\
3.6 \\
8 \\
0.2 \\
0.1 \\
0.4 \\
-\end{array}$ & $\begin{array}{c}0.001 \\
0.72 \\
0.1 \\
0.2 \\
0.2 \\
0.6 \\
0.3 \\
-\end{array}$ \\
\hline No known comorbidities & 3,509 & 80 & 2941 & 83 & 568 & 67 & $<0.001^{*}$ \\
\hline $\begin{array}{l}\text { Comorbidities } \\
\text { Diabetes } \\
\text { Hypertension } \\
\text { Obesity } \\
\text { Chronic kidney disease } \\
\text { Cancer } \\
\text { Heart disease } \\
\text { Autoimmune disease } \\
\text { Hypothyroidism } \\
\text { Asthma } \\
\text { HIV }\end{array}$ & $\begin{array}{c}892 \\
392 \\
345 \\
272 \\
60 \\
22 \\
23 \\
20 \\
21 \\
15 \\
11\end{array}$ & $\begin{array}{c}20 \\
9 \\
8 \\
6 \\
1.4 \\
0.5 \\
0.5 \\
0.5 \\
0.5 \\
0.3 \\
0.2\end{array}$ & $\begin{array}{c}612 \\
286 \\
249 \\
203 \\
41 \\
11 \\
13 \\
15 \\
15 \\
12 \\
9\end{array}$ & $\begin{array}{c}17 \\
8 \\
7 \\
5 \\
1 \\
0.3 \\
0.4 \\
0.4 \\
0.0 \\
0.3 \\
0.2\end{array}$ & $\begin{array}{c}280 \\
106 \\
96 \\
69 \\
19 \\
11 \\
10 \\
5 \\
6 \\
3 \\
2\end{array}$ & $\begin{array}{c}33 \\
12.5 \\
11.3 \\
8.1 \\
2.2 \\
1.3 \\
1.2 \\
0.6 \\
0.7 \\
0.4 \\
0.2\end{array}$ & $\begin{array}{c}<0.001 \\
<0.001 \\
0.11 \\
0.21 \\
0.001 \\
0.007 \\
0.5 \\
0.2 \\
0.5 \\
0.6\end{array}$ \\
\hline
\end{tabular}

IQR = interquartile range.

*Fisher's exact test. **Mann-Whitney's U-test.

Table 2. Age of patients hospitalized at Central Military Hospital, Mexico City

\begin{tabular}{|c|c|c|c|c|c|c|}
\hline \multirow[t]{2}{*}{$\begin{array}{l}\text { Age range } \\
\text { (years) }\end{array}$} & \multicolumn{2}{|c|}{$\begin{array}{c}\text { Total } \\
(\mathrm{n}=\mathbf{4 , 4 0 1 )}\end{array}$} & \multicolumn{2}{|c|}{$\begin{array}{c}\text { Males } \\
(n=2,666)\end{array}$} & \multicolumn{2}{|c|}{$\begin{array}{l}\text { Females } \\
(n=1,735)\end{array}$} \\
\hline & $\mathrm{n}$ & $\%$ & $\mathrm{n}$ & $\%$ & $n$ & $\%$ \\
\hline$<20$ & 67 & 1.5 & 27 & 1 & 40 & 2.3 \\
\hline $21-30$ & 442 & 10 & 216 & 8 & 226 & 13 \\
\hline $31-40$ & 776 & 17.6 & 501 & 19 & 275 & 16 \\
\hline $41-50$ & 1,009 & 23 & 703 & 26 & 306 & 17.6 \\
\hline $51-60$ & 856 & 19.5 & 519 & 19.5 & 337 & 19.4 \\
\hline $61-70$ & 656 & 15 & 394 & 15 & 262 & 15 \\
\hline $71-80$ & 418 & 9.5 & 210 & 8 & 208 & 12 \\
\hline $81-90$ & 161 & 3.7 & 89 & 3.3 & 72 & 4 \\
\hline $91-100$ & 16 & 0.4 & 7 & 0.3 & 9 & 0.5 \\
\hline
\end{tabular}

doubled between the second, third, fourth and fifth decades of life, and between the latter and the 61 to 70 group, it increased by $14.6 \%$; in turn, between this group and the next one, it only increased by $1.8 \%$ and subsequently it only increased by $6.6 \%$ (Table 4).

In patients younger than 51 years of age, the crude case fatality rate in men was $11.8 \%(172 / 1,447)$, while in women it was $6.1 \%(52 / 847)$, which represented a male:female ratio of 1.98:1. On the other hand, in those older than 51 years of age, the crude case fatality rate in male patients was $44.3 \%(541 / 1,219)$, and in female patients, $33.1 \%$ (294/888); this represented a male:female ratio of 1.33:1 (Table 4).

Most deceased patients did not have any comorbidity; among the 390 patients with comorbidities, the 
Maza-De la Torre G, et al.: Epidemiology of hospitalized patients with COVID-19

Table 3. Nutritional status of COVID-19-confirmed patients hospitalized at Central Military Hospital, Mexico City

\begin{tabular}{|c|c|c|c|c|c|c|c|}
\hline BMI $\left(\mathrm{kg} / \mathrm{m}^{2}\right)$ & & & Recc & & Dec & & p \\
\hline Median (IQR) & $27.1(2$ & 9.4) & 27( & & $27.2(2$ & 9.7) & 0.03 \\
\hline Category & Rate* $^{*}$ & $\%$ & Rate* $^{*}$ & $\%$ & Rate* & $\%$ & \\
\hline$<25$, normal & $151 / 656$ & 23 & $108 / 418$ & 25.8 & $43 / 238$ & 18 & 0.02 \\
\hline 25-29.9, overweight & $372 / 656$ & 56 & $235 / 418$ & 56.2 & $137 / 238$ & 57.5 & 0.74 \\
\hline 30-34.9, grade I obesity & $93 / 656$ & 14.1 & $50 / 418$ & 11.9 & $43 / 238$ & 18.0 & 0.03 \\
\hline 35-39.9, grade II obesity & 29/656 & 4.4 & $18 / 418$ & 4.1 & $11 / 238$ & 4.6 & 0.84 \\
\hline$\geq 40$, grade III obesity & $11 / 656$ & 1.6 & $7 / 418$ & 1.6 & $4 / 238$ & 1.6 & 0.61 \\
\hline
\end{tabular}

$\mathrm{IQR}=$ interquartile range

${ }^{*}$ Rate of patients/hospitalized patients

Table 4. COVID-19 deaths at Central Military Hospital, Mexico City

\begin{tabular}{|c|c|c|c|c|c|c|c|}
\hline$(\mathrm{N}=4,401)$ & \multicolumn{2}{|c|}{$\begin{array}{c}\text { Total } \\
(n=1,059,24 \%)\end{array}$} & \multicolumn{2}{|c|}{$\begin{array}{l}\text { Suspected } \\
(827=23)\end{array}$} & \multicolumn{2}{|c|}{$\begin{array}{l}\text { Confirmed } \\
(232=27)\end{array}$} & $p$ \\
\hline \multirow[t]{2}{*}{ Median age, years (IQR) } & \multicolumn{2}{|c|}{$62(53,71)$} & \multicolumn{2}{|c|}{$62(53,72)$} & \multicolumn{2}{|c|}{$61(51,71)$} & $<0.001^{*}$ \\
\hline & n & $\begin{array}{c}\text { Crude case } \\
\text { fatality rate } \%\end{array}$ & n & $\begin{array}{c}\text { Crude case } \\
\text { fatality rate } \%\end{array}$ & n & $\begin{array}{c}\text { Crude case } \\
\text { fatality rate } \%\end{array}$ & \\
\hline $\begin{array}{l}\text { Gender } \\
\text { Males } \\
\text { Females }\end{array}$ & $\begin{array}{l}713 \\
346\end{array}$ & $\begin{array}{l}67 \\
33\end{array}$ & $\begin{array}{l}541 \\
286\end{array}$ & $\begin{array}{l}65 \\
35\end{array}$ & $\begin{array}{l}172 \\
60\end{array}$ & $\begin{array}{l}74 \\
26\end{array}$ & $0.01^{\star \star}$ \\
\hline $\begin{array}{l}\text { Blood group } \\
\begin{array}{l}\mathrm{O}_{+} \\
\mathrm{A}_{+} \\
\mathrm{B}+ \\
\mathrm{O}_{-} \\
\mathrm{A}- \\
\mathrm{B}- \\
\mathrm{AB}+\end{array}\end{array}$ & $\begin{array}{c}930 \\
90 \\
22 \\
10 \\
1 \\
2 \\
4\end{array}$ & $\begin{array}{c}88 \\
9 \\
2 \\
1 \\
0.1 \\
0.2 \\
0.4\end{array}$ & $\begin{array}{c}719 \\
77 \\
16 \\
8 \\
1 \\
2 \\
4\end{array}$ & $\begin{array}{c}87 \\
9 \\
1.9 \\
0.9 \\
0.1 \\
0.2 \\
0.4\end{array}$ & $\begin{array}{c}211 \\
13 \\
6 \\
2\end{array}$ & $\begin{array}{l}91 \\
5.6 \\
2.5 \\
0.8\end{array}$ & $\begin{array}{c}0.04^{\star *} \\
0.89 \\
0.6 \\
1\end{array}$ \\
\hline No known comorbidities & 669 & 63 & 552 & 67 & 117 & 50 & \\
\hline $\begin{array}{l}\text { Comorbidities } \\
\text { Diabetes } \\
\text { Hypertension } \\
\text { Obesity } \\
\text { Chronic kidney disease } \\
\text { Cancer } \\
\text { Heart disease } \\
\text { Autoimmune disease } \\
\text { Hypothyroidism } \\
\text { Asthma }\end{array}$ & $\begin{array}{c}90 \\
219 \\
193 \\
123 \\
30 \\
7 \\
12 \\
6 \\
4 \\
6\end{array}$ & $\begin{array}{c}37 \\
21 \\
18 \\
12 \\
3 \\
1 \\
1 \\
0.6 \\
0.4 \\
0.6\end{array}$ & $\begin{array}{c}275 \\
165 \\
147 \\
90 \\
24 \\
3 \\
8 \\
3 \\
1 \\
4\end{array}$ & $\begin{array}{c}33 \\
20 \\
17 \\
10 \\
2.9 \\
3 \\
9 \\
0.3 \\
0.1 \\
0.4\end{array}$ & $\begin{array}{l}115 \\
54 \\
46 \\
33 \\
6 \\
4 \\
4 \\
3 \\
3 \\
2\end{array}$ & $\begin{array}{l}50 \\
23 \\
20 \\
14 \\
2.5 \\
1.7 \\
1.7 \\
1.3 \\
1.3 \\
0.8\end{array}$ & $\begin{array}{c}0.4 \\
0.4 \\
0.1 \\
1 \\
0.04 \\
0.3 \\
0.1 \\
0.03 \\
0.6\end{array}$ \\
\hline
\end{tabular}

$\mathrm{IQR}=$ interquartile range.

*Mann-Whitney's U-test.

**Fisher's exact test.

main one was diabetes, followed by hypertension and obesity (Table 4).

In a sample of 656 confirmed patients, median BMI was similar between recovered patients and those who died; only $23 \%$ had normal weight, which was predominant in recovered patients vs. deceased patients. No significant difference was found in patients with grade II and III overweight or obesity between those who recovered and those who died, but a significant difference was observed in patients with 
Table 5. Age range of patients who died from COVID-19 at Central Military Hospital, Mexico City

\begin{tabular}{|l|c|c|c|c|c|c|c|}
\hline \multirow{2}{*}{ Age range (years) } & \multicolumn{3}{|c|}{ Total } & \multicolumn{3}{c|}{ Males } & \multicolumn{2}{c|}{ Females $^{*}$} \\
\cline { 2 - 7 } & Rate* & $\%$ & Rate* & $\%$ & Rate* & $\%$ \\
\hline$<20$ & $2 / 67$ & 2.99 & $0 / 27$ & 0 & $2 / 40$ & 5 & 0.5 \\
\hline $21-30$ & $12 / 442$ & 2.71 & $7 / 216$ & 3.24 & $5 / 226$ & 2.21 & 0.5 \\
\hline $31-40$ & $57 / 776$ & 7.35 & $39 / 501$ & 7.78 & $18 / 275$ & 6.55 & 0.4 \\
\hline $41-50$ & $153 / 1,009$ & 15.16 & $126 / 703$ & 17.92 & $27 / 306$ & 8.82 & 0.001 \\
\hline $51-60$ & $255 / 856$ & 29.79 & $180 / 519$ & 34.68 & $75 / 337$ & 22.26 & 0.004 \\
\hline $61-70$ & $291 / 656$ & 44.36 & $198 / 394$ & 50.25 & $93 / 262$ & 35.50 & 0.02 \\
\hline $71-80$ & $193 / 418$ & 46.17 & $105 / 210$ & 50 & $88 / 208$ & 42.31 & 0.3 \\
\hline $81-90$ & $85 / 161$ & 52.8 & $52 / 89$ & 58.43 & $33 / 72$ & 45.83 & 0.4 \\
\hline $91-100$ & $11 / 16$ & 68.75 & $6 / 7$ & 85.7 & $5 / 9$ & 55.56 & 0.7 \\
\hline Total & $1,059 / 4,401$ & 24 & $713 / 2,666$ & 26.7 & $346 / 1,735$ & 19.9 \\
\hline
\end{tabular}

${ }^{*}$ Rate of deceased patients/hospitalized patients.



Figure 3. Kaplan-Meier analysis of COVID-19 deaths at Central Military Hospital, Mexico City.

grade I obesity (Table 3). These data identify overweight as the main comorbidity in those patients who died.

Hospital stay analysis in those patients who died showed a median of six days $(95 \% \mathrm{Cl}=5.5,6.4)$, as shown in figure 3 .

\section{Discussion}

This study describes the epidemiological characteristics of 4,401 patients with COVID-19 at Central Military Hospital, where more patients were admitted during the analyzed period in comparison with 1300 patients cared for from May to the second week of July in the COVID hospital at Mexico City's racetrack. ${ }^{5}$
At the national level, confirmed cases exponentially increased from May 12 on; at Central Military Hospital, the highest number of hospitalized patients occurred between May and June, with a maximum peak on May $29 .^{2}$

Male gender predominated, similar to the reports in Mexico by Ortiz Brizuela et al., by Wei-Jie Guan et al. in Chinese population, Jaime Berumen et al. in a case-control study based on the reports of the Mexican Ministry of Health, and another involving 12 hospitals of the Northwell health system, in New York, USA ${ }^{6-10}$ This is consistent with the reports on the predisposition of men for developing viral infections related to the inhibitory effect of testosterone on T-helper cells (Th1) differentiation, with a consequent decrease in the production of IFN- $\alpha .{ }^{11}$

At "Salvador Zubirán" National Institute of Medical Sciences and Nutrition, median age was found to be 49 years, as in our study and similar to that reported in the Chinese population. In the Central Military Hospital population, $>80 \%$ of hospitalized subjects were between 30 and 80 years of age; in the New York study, median age was 63 years. , $, 8,12-13$ Distribution by age group in our research was similar to that recorded by Jaime Berumen et al., who identified that most patients were between 51 and 60 years of age, while at Central Military Hospital, most patients were aged between 41 and 50 years, which is consistent with the observation that risk is higher as age increases. ${ }^{10}$

In those patients with COVID-19 from the hospital where we conducted our research, blood group $\mathrm{O}_{+}$ 
predominated, followed by $\mathrm{A}+$, similar to that reported for the general population in 2018. ${ }^{14}$ Positive Rh factor also predominated. In the New York study on Hispanic population with COVID-19, blood group O+ also predominated, followed by the A+ group, even when group $O$ has been reported to be a protective factor against SARS-CoV-1. ${ }^{15}$

As for comorbidities, at Central Military Hospital we found that only $20 \%$ of patients had comorbidities, similar to that reported in China $(25.1 \%) .{ }^{16}$ In contrast, in New York all patients had at least one comorbidity. ${ }^{8}$

The order of comorbidities was diabetes, hypertension and obesity, which differs from other reports in Mexico, although in the studies by Jaime Berumen et al. and Ortiz Brizuela et al., these are indicated to be the main comorbidities. $2,6,10$

In 656 confirmed patients, $56 \%$ were found to be overweight, which turns overweight into the main comorbidity and is consistent with the results obtained by Ortiz Brizuela et al., although median BMI in our study was lower. ${ }^{6}$

If overweight is regarded as the main comorbidity in confirmed patients, followed by diabetes and hypertension, the results would agree with those obtained by Hernández Garduño, who identified obesity as the main risk factor for infection, followed by diabetes and hypertension. This is probably due to the increased levels of angiotensin-converting enzyme-2 (ACE-2) receptors in adipose tissue, which constitute the entry mechanism for SARS-CoV-2.17-19

At General Hospital of Mexico, a crude case fatality rate of $46.8 \%$ was recorded ${ }^{20}$, whereas at Central Military Hospital it was $24 \%$, which is similar to the crude fatality rate recorded at Pemex $(29 \%)^{21}$ and to those reported in New York (21\%) and China (28\%). ${ }^{8}$

In our study, male patient deaths predominated, which is similar to information in national reports (52.24\%); ${ }^{2}$ however, in China and New York, the male:female ratio was 1:1.,22

The finding that the rate of deceased males/hospitalized males was higher than the rate of deceased females/hospitalized females is consistent with reports of other series and meta-analyses, where the male gender was found to have a higher risk of infection, clinical deterioration and death..$^{10,11,23}$ This is probably due to the predisposition men have for acquiring viral infections and experiencing more complications due to a lower production of INF- $\alpha$ in response to TLR7, as well as to IL-10 elevated levels in response to TLR8 and TLR9 activation; in contrast, women have the protective role of estrogens, such as $17 \beta$-estradiol, which stimulate cellular and humoral immunity to viral infections. ${ }^{11,24}$

Regarding the age of those patients who died, the median was 62 years; in China, a similar age was reported (57 years). According to analyses from China, Italy, Spain, New York, and the United Kingdom, an age older than 50 is associated with COVID-19 case fatality rate; the risk is even higher in patients older than 60 years. $^{22}$

Comparing the case fatality rates by age groups, they were higher in all age groups in comparison with those of the New York study and were only similar in the 81-90 years group. ${ }^{8}$ In the reports from China, Italy, Spain, New York and the United Kingdom, crude case fatality rate by age group was $<30 \%$ in those younger than 70 years; in our study, the $51-60$ years age group had a crude fatality rate of $29.79 \%$, and of $34.68 \%$ in male patients. ${ }^{22}$

In addition to the fact that before 51 years of age the male:female ratio is higher than after that age, these results agree with observations in postmenopausal women (aged $>45$ years), who had more symptoms and longer hospitalization time, probably because they lose the protection conferred by estrogens. ${ }^{11,25}$

Regarding the blood group, the O+ group predominated in those patients who died, unlike the observations reported by Zietz et al. ${ }^{15}$

In our study, diabetes prevailed in those patients who died, followed by hypertension and obesity, which have been pointed at as predisposing factors for infection and severity. ${ }^{26}$ However, according to the BMI, the main comorbidity was overweight.

Various studies consider overweight and obesity to be factors of poor prognosis, severity, admission to intensive care unit requirement, and mortality, due to an increase in ACE-2 receptors in adipose tissue, ${ }^{17-18,23,27}$ coupled with the fact that adipose tissue promotes the production of pro-inflammatory cytokines and induces chronic systemic inflammation. Patients with obesity and COVID-19 exhibit a higher inflammatory response and risk for developing cytokine storm..$^{18}$ Another proposed mechanism is associated with regulatory $\mathrm{T}$ cells, particularly Th17 cells, related to IL-6, IL-24/IL-17, as well as to other cytokines such as TNF- $\alpha$ or TGF. ${ }^{27}$

Median hospital stay in those patients who died was longer in our study than in the study conducted in New York (4.1 days). ${ }^{8}$ 


\section{Conclusion}

The age of patients hospitalized at Central Military Hospital with a COVID-19 diagnosis was similar to that reported at the national level, as well as to that recorded in Pemex, but lower when compared to that referred in other tertiary care centers in Mexico. The predominant blood group was $\mathrm{O}+$. Most hospitalized patients who died from COVID-19 were older than 60 years, as it has been reported in other countries. In those patients who died, the male gender was observed to predominate, although in the group older than 51 years, the frequency of female patients did increase. On the other hand, more than $40 \%$ of those patients who died had no comorbidities; among these, the most prevalent were overweight and diabetes, which have already been referred to as risk factors for higher severity and complications. In $50 \%$ of those patients who died, death occurred within the first six days after hospital admission.

\section{Acknowledgements}

Our gratitude and sincere recognition to the work of all personnel of the Central Military Hospital of the Ministry of National Defense during the COVID-19 health contingency.

\section{Funding}

This project did not require any funding.

\section{Conflict of interests}

The authors declare that they have no conflicts of interest.

\section{Ethical disclosures}

Protection of human and animal subjects. The authors declare that no experiments were performed on humans or animals for this research.

Confidentiality of data. The authors declare that no patient data appear in this article.

Right to privacy and informed consent. The authors declare that no patient data appear in this article.

\section{References}

1. Zhou F, Yu T, Du R, Fan G, Liu Y, Liu Z, et al. Clinical course and risk factors for mortality of adult inpatients with COVID-19 in Wuhan, China: a retrospective cohort study. Lancet. 2020;395:1054-1062.

2. Consejo Nacional de Ciencia y Tecnología [Internet]. Mexico: Covid-19 México; 2020.

3. Dirección General de Epidemiología. Lineamiento estandarizado para la vigilancia epidemiológica y por laboratorio de la enfermedad respiratoria viral. Mexico: Secretaría de Salud; 2020.

4. Dirección General de Epidemiología. Lineamiento de reconversión hospitalaria. Mexico: Secretaría de Salud; 2020.

5. Cruz-Martínez A. Ha atendido 1,300 pacientes el hospital Covid Autódromo. La Jornada [Internet]. 2020 Jul 16.

6. Ortiz-Brizuela E, Villanueva-Reza M, González-Lara MF, Tamez-Torres KM, Román-Montes CM, Díaz-Mejía BA, et al. Clinical and epidemiological characteristics of patients diagnosed with COVID-19 in a tertiary care center in Mexico City: a prospective cohort study. Rev Investig Clin. 2020;72:165-177.

7. Guan WJ, Ni Si, Ha Y, Ligan W, Ou Cd, He Ja, et al. Clinical characteristics of 2019 novel coronavirus infection in China. medRxiv. 2020:1-7.

8. Richardson S, Hirsch JS, Narasimhan M, Crawford JM, McGinn T, Davidson $\mathrm{KW}$, et al. Presenting characteristics, comorbidities, and outcomes among 5700 patients hospitalized with COVID-19 in the New York City area. JAMA. 2020;323:2052-2059.

9. Li LQ, Huang T, Wang YQ, Wang ZP, Liang Y, Huang TB, et al. COVID-19 patients' clinical characteristics, discharge rate, and fatality rate of meta-analysis. J Med Virol. 2020:92:577-583.

10. Berumen J, Schmulson M, Alegre-Díaz J, Guerrero G, Larriva-Sahd J, Wong-Chew RM, et al. Risk of infection and hospitalization by Covid-19 in Mexico: a case-control study. medRxiv. 2020:1-26.

11. Grandi G, Facchinetti F, Bitzer J. The gendered impact of coronavirus disease (COVID-19): do estrogens play a role? Eur J Contracept Reprod Heal Care. 2020;25:233-234.

12. Tu H, Tu S, Gao S, Shao A, Sheng J. Current epidemiological and clinical features of COVID-19; a global perspective from China. J Infect. 2020;81:1-9.

13. Siordia JA. Epidemiology and clinical features of COVID-19: A review of current literature. J Clin Virol. 2020:127:104357.

14. Canizalez-Román A, Campos-Romero A, Castro-Sánchez JA, et al. Blood groups distribution and gene diversity of the ABO and Rh (D) Loci in the Mexican population. Biomed Res Int. 2018;2018:1925619.

15. Zietz M, Zucker J, Tatonetti N. Testing the Association between blood type and COVID-19 infection, intubation, and death. medRxiv. 2020.

16. Liang W, Liang $\mathrm{H}, \mathrm{Ou} \mathrm{L}$, Chen B, Chen A, Li C, et al. Development and validation of a clinical risk score to predict the occurrence of critical illness in hospitalized patients with COVID-19. JAMA Intern Med. 2020;180:1-9.

17. Zhao J, Yuan Q, Wang H, Liu W, Liao X, Su Y, et al. Antibody responses to SARS-CoV-2 in patients of novel coronavirus disease 2019. Clin Infect Dis. 2020;71:2027-2034.

18. Lui B, Samuels JD, White RS. Potential pathophysiology of COVID-19 in patients with obesity. Br J Anaesth. 2020;125:e282-e284.

19. Hernández-Garduño $E$. Obesity is the comorbidity more strongly associated for COVID-19 in Mexico. A case-control study. Obes Res Clin Pract. 2020;14:375-379.

20. Hospital General ha atendido a más de 3 mil pacientes con covid-19 y 500 trabajadores. Milenio [Internet]. 2020 Aug 10.

21. Petróleos Mexicanos [Internet]. Mexico: Reporte de estado de salud de trabajadores y derechohabientes de PEMEX afectados por COVID-19; 2020.

22. Bonanad C, García-Blas S, Tarazona-Santabalbina F, Sanchis J, Bertomeu-González V, Fácila L, et al. The effect of age on mortality in patients with COVID-19: a meta-analysis with 611,583 subjects. J Am Med Dir Assoc. 2020;21:915-918.

23. Caramelo F, Ferreira N, Oliveiros B. Estimation of risk factors for COVID-19 mortality - preliminary results. medRxiv. 2020.

24. Torcia MG, Nencioni L, Clemente AM, Civitelli L, Celestino I, Limongi D, et al. Sex differences in the response to viral infections: TLR8 and TLR9 ligand stimulation induce higher IL10 production in males. PLoS One. 2012;7:e39853.

25. Costeira R, Lee KA, Murray B, Christiansen C, Castillo-Fernández J, Lochlainn MN, et al. Estrogen and COVID-19 symptoms: associations in women from the COVID Symptom Study. medRxiv. 2020.

26. Sanyaolu A, Okorie C, Marinkovic A, Patidar R, Younis K, Desai P, et al. Comorbidity and its impact on patients with COVID-19. SN Compr Clin Med. 2020:1-8.

27. Petrakis D, Margină D, Tsarouhas K, Tekos F, Stan M, Nikitovic D, et al. Obesity - a risk factor for increased COVID-19 prevalence, severity and lethality (Review). Mol Med Rep. 2020;22:9-19. 